\title{
НАПРАВЛЕНИЯ СОТРУДНИЧЕСТВА ГОСУДАРСТВА И БИЗНЕСА В КОНТЕКСТЕ СОВРЕМЕННЫХ ВЫЗОВОВ В РОССИИ
}

\author{
(c) 2021 Рабаданова Амина Асадовна \\ кандидат экономических наук \\ Институт экономики РАН, Россия, Москва
}

В статье предложены направления взаимодействия государства и бизнеса в связи с происходящими социально-экономическими процессами в России и мире. Идеи социального государства выдвигают на первый план задачу сохранения населения и его благополучия, вследствие чего особую актуальность обретают проекты ГЧП по развитию социальной инфраструктуры и социального обслуживания, IT-сферы, туризма.

Ключевые слова: взаимодействие государства и бизнеса, партнерство, проекты ГЧП, постпандемия.

Восстановление национальной экономики и «рубцевание шрамов» после пандемии, несомненно, являются главным вызовом современности, как в России, так и мире в целом. Тренд на модель «ответственного государства» с иерархичной организацией экономики и огосударствлением отдельных секторов в разгар кризиса сменяется идеями социального государства в постпандемию. Государственная модель управления и бизнес-модели компаний меняются в направлении формирования экосистемы вокруг человека: его здоровья, безопасности, качества жизни. О чем свидетельствует Указ В.В.Путина о национальных целях развития России до 2030 года, где основными приоритетами на ближайшее десятилетие выдвинуты:

- сохранение населения, здоровье и благополучие людей;

- возможности для самореализации и развития талантов;

- комфортная и безопасная среда для жизни;

- достойный, эффективный труд и успешное предпринимательство;

- цифровая трансформация [7].

По мнению экспертов, развитие российских компаний в постпандемию также будет связано с цифровизацией бизнес-процессов и повышением роли человеческого капитала [5].

Государство и бизнес должны рассматриваться как равноправные партнеры в реализации функций по обеспечению интересов развития каждого человека и общества в целом. Необходим отход от властно-директивных методов управления и административного при- нуждения к признанию важности кооперации между государством и бизнес-сообществом [4].

Пандемия и кризис подтолкнули российские компании и государственные органы к активному взаимодействию. Цифровизация создает новую платформу для сотрудничества с частным сектором экономики и координации изменений [6]. И в этих условиях важно ограничить чрезмерный контроль бизнеса со стороны государственных органов и встраивание его в исполнение решений «сверху вниз». С одной стороны, это может обеспечить согласованность структурных изменений, но с другой - создать ограниченность рыночных стимулов.

Призма взаимоотношений «государство бизнес - человек» предполагает новые отношения в разделении ролей. Происходит с одной стороны разделение ответственности, с другой, разделение труда между государством и бизнессообществом. Отношения между государством и частным бизнесом формируются не в системе административного подчинения, а в системе правовой регуляции, где происходит отход от публично-правовых отношений администрирования, к частно-правовым отношениям - взаимодействию [1].

Во многих западных странах основы такой государственности имеют прочную законодательную базу. В России же в силу относительной молодости правовой системы в сравнении с западными странами и недостаточно созревшей культуры ответственности государственночастного партнерства, такая база недостаточна и ее необходимо нарабатывать.

Тем не менее, за последние годы есть и по- 
зитивные тенденции развития партнерских отношений государства и бизнеса в России. В проектах ГЧП растет объем частных инвестиций. По итогам 2020 года общий объем проектов ГЧП составил 356 млрд. рублей, из них 80\% - средства инвесторов. Еще пару лет назад этот показатель составлял около 50\%. Расширяется и отраслевая специфика проектов - увеличилось число проектов в социальном секторе, активно формируется практика в сфере IT, есть спрос на проекты благоустройства.

Обеспечение благосостояния граждан и удовлетворение социальных потребностей зависит в первую очередь от качества социальной инфраструктуры. В России формируется рынок частных операторов в системе образования, здравоохранения и социального обслуживания, что в перспективе позволит применять различные модели ГЧП для эффективного управления социальной инфраструктурой.

В текущем году запущена самая масштабная за последние пять лет программа поддержки инфраструктурных проектов - программа по строительству школ по ГЧП, предусматривающая выделение федерального софинансирования. По ней уже отобрано 74 концессионных проекта, более 250 проектов находятся в обработке. Также утверждены правила финансирования проектов по созданию университетских кампусов, предусматривающие использование механизмов ГЧП. Стоит отметить пример сотрудничества государства и бизнеса и в сфере информатизации образования - проект «Школьный портал» Московской области, который уже активно используют все муниципальные и государственные школы региона.

А вот в здравоохранении, несмотря на то, что в отрасль вложен огромный объем финансовых средств на фоне пандемии, не хватает механизмов поддержки частных инвестиций, аналогичных, к примеру, программе строительства школ по ГЧП [2]. Государством на протяжении последних десятилетий уделялось повышенное внимание развитию отдельных направлений здравоохранения, наиболее привлекательных потенциальным частным инвесторам: специализированная и высокотехнологичная медицинская помощь; инновационная медицинская помощь (протонно-лучевая терапия, ядерная медицина, телемедицина, клеточная медицина и др.); первичная медико-санитарная помощь; медицинская реабилитация и санаторно- курортное лечение. Одними из лучших проектов в практике ГЧП в сфере здравоохранения являются Центр экстракорпоральной гемокоррекции и трансклинической фузиологии Самарской области и Сеть центров врачей общей практики в муниципальных образованиях в Ульяновской области.

Среди реализуемых проектов значительное внимание уделяется высокотехнологичной и специализированной помощи, в то время как медицинская реабилитация и санаторнокурортное лечение сильно отстают. В отраслевом разрезе частных инвестиций в рамках ГЧП предпочтение отдается более сложным и наукоемким сферам. На сегодняшний день в инновационной медицине реализуется более 60 проектов ГЧП, половина из которых - в форме концессионного соглашения [3].

Среди дополнительных инструментов привлечения и поддержки частных инвесторов в проекты ГЧП в сфере здравоохранения (в форме концессионного соглашения) можно предложить следующие:

- смягчение законодательных требований к структуре тарифа OMC, а также увязка сроков концессионных соглашений и тарифных соглашений с целью снижения коммерческих рисков для частных инвесторов;

- выбор операционной модели деятельности будущего частного партнера на этапе проработки концепции проекта (емкость услуг, оказываемая по тарифам обязательного/добровольного медицинского страхования или полностью платная);

- разрешение земельно-имущественных взаимоотношений сторон (на момент заключения концессионного соглашения объект здравоохранения должен быть свободен от прав третьих лиц). [3]

Сложившаяся ситуация в мире выдвигает туризм как одну из перспективных отраслей развития в российских регионах. Принятие нацпроекта «Туризм и индустрия гостеприимства» будет способствовать запуску новых масштабных проектов и привлечению инвестиций в развитие туристской инфраструктуры. Переориентация россиян на внутренние направления в связи с закрытием международных границ изза пандемии, резко увеличила туристический поток в регионы страны. Также необходимость реабилитации и восстановления здоровья населения в постпандемию вызывает актуальность 
создания рекреационных зон для отдыха и досуга в регионах с благоприятными природноклиматическими условиями. С этой позиции опыт ОЭЗ туристско-рекреационного типа в российских регионах может стать перспективным примером сотрудничества государства и бизнеса в сложившихся условиях. На территории РФ функционируют 10 туристско-рекреационных ОЭ3, резидентами которых по состоянию на октябрь 2021 г. создано 873 рабочих мест, осуществлено 5,77 млрд. рублей инвестиций, объем выручки составил 2,63 млрд. рублей, уплачено 0,42 млрд. рублей налоговых, таможенных отчислений и отчислений в государственные внебюджетные фонды. Несмотря на то, что туристско-рекреационные зоны требуют меньших организационных усилий и финансовых затрат по сравнению с ОЭЗ других типов, тем не менее они имеют низкую рентабельность в России. Это связано с тем, что большинство туристических проектов ОЭЗ инфраструктурные, по факту решающие задачу освоения и использования уникальных природных ресурсов страны.

При этом эффективность взаимодействия государства и бизнеса в рамках функционирования ОЭЗ ТРТ, учитывая особенности их развития, могут повысить ряд мероприятий:

- определение чётких показателей эффективности проектов ОЭЗ ТРТ;

- обозначение границ личной ответственности топ-менеджмента;

- создание эффективной системы поддержки, внедрение финансовых инструментов;

- разработка генерального плана развития курортов в ОЭЗ (большое количество спорных территорий и строений тормозит развитие туристической зоны и делает ее менее привлекательной с точки зрения захода крупных инвесторов);

- внедрение механизма льготного кредитования представителей туриндустрии для строительства мест размещения;

- комплексный подход к территориям ОЭЗ ТРТ (развлечения, этнографическая составляющая, позиционирование и т.д.).

Актуальность государственно-частного партнерства в IT-сфере, в реализации проектов с использованием цифровых технологий, в том числе и в регионах, на сегодняшний день очень высока, но примеров таких проектов не много. До недавнего времени, объекты IT не входили в перечень объектов концессионных соглашений и соглашений о ГЧП. Вступивший в силу 173Ф3 в 2018 году о внесении поправок устранил данный пробел в законодательстве РФ, добавив объекты IT в перечень объектов, в отношении которых могут быть заключены концессионные соглашения и соглашения о ГЧП.

Среди проблем, ограничивающих развитие ГЧП в ІТ-сфере, можно выделить:

- низкий уровень компетенций у государственных органов и частных инвесторов для работы с проектами на «нулевой» стадии;

- отсутствие отдельных механизмов господдержки в виде софинансирования ГЧП-проектов в IT сфере в федеральных программах;

- правовая «незрелость» отрасли в вопросах монетизации данных;

- правовые ограничения для применения в муниципальных системах и привлечении иностранных инвесторов.

В условиях стремительного развития IT-рынка необходимо постепенно отходить от «классических» форм взаимодействия государства и бизнеса (государственный заказ, государственная поддержка, стратегическое партнерство) к более сложному «инфраструктурному партнерству» (концессионные соглашения, соглашения о ГЧП/МЧП, долгосрочные контракты на принципах КЖЦ, создание СПК). В результате перехода к таким формам ГЧП бизнес сможет предложить более современные решения в рамках проекта, таким образов восполнив возможный недостаток компетенций у госзаказчика.

Таким образом, в контексте современных вызовов взаимодействие государства и бизнеса должно рассматриваться как социальный институт, регулирующий взаимоотношения между государством и бизнесом для решения социально-экономических проблем общества, приобретающий форму корпоративносоциальной ответственности. При этом наиболее актуальными направлениями партнерства государства и частного сектора в условиях постпандемии являются проекты по развитию социальной инфраструктуры и социального обслуживания, IT-сферы, туризма. 


\section{Библиографический список}

1. Александров О.Г. Современное государственное управление в России: развитие маркетинговой модели или возврат к административно-бюрократической системе? / О.Г. Александров // Стратегии развития социальных общностей, институтов и территорий: материалы II Международн. науч.-практ. конф. Екатеринбург, 18-20 апреля 2016 г.: в 2-х т.-Екатеринбург: Изд-во Урал. ун-та, 2016. - Т. 1.- С. 60-66.

2. В пандемию количество ГЧП-проектов сократилось на 40\%: [Электронный ресурс] 2021 г. URL: https:// rg.ru/2021/09/22/v-pandemiiu-kolichestvo-gchp-proektov-sokratilos-na-40.html

3. Дабагян Е.К. Особенности развития государственно-частного партнерства общественном секторе экономики / 112 Е.К.Дабагян // Аналитический журнал «РИСК»: Ресурсы информация снабжение конкуренция».-2015. - № 24.- С. 161-166.

4. Зельднер А.Г. Эффективное управление как процесс, отражающий уровень компетенции исполнительной власти // Проблемы теории и практики управления. 2020. № 6. с. 6-16.

5. Оценка влияния кризиса, связанного с пандемией COVID-19, на отрасли российской экономики и их посткризисное развитие: докл. к XXII Апр. междунар. науч. конф. по проблемам развития экономики и общества, Москва, 13-30 апр. 2021 г. / Ю. В. Симачев (рук. авт. кол.), Н. В. Акиндинова, М. Н. Глухова и др.- М.: Изд. дом Высшей школы экономики, 2021.-45 с.

6. Смотрицкая И. И. Цифровая трансформация государственного управления: основные тренды и новые возможности // Научные труды Вольного экономического общества России. 2021. Т. 230. № 4. С. $223-229$.

7. Указ Президента Российской Федерации от 21.07.2020 № 474 «О национальных целях развития Российской Федерации на период до 2030 года». 